\title{
THE PRINCIPLES GOVERNING AWARDS OF DAMAGES UNDER THE FATAL ACCIDENTS ACT
}

\author{
A. F. Moir, B.A., LL.B., LL.M., of Wood, Haddad, Moir, Hyde and Ross \\ and D. J. Horne, Second Year Law.
}

One indirect result of the invention of the internal combustion engine which has greatly influenced the life of the legal practitioner has been a rise of damage claims created as the result of traffic accidents. These actions for personal injuries are constantly taking up a greater portion of the cases brought on for trial in the common law jurisdictions throughout the world, and the judgments for damages which result from such actions have a tendency to set precedents in their particular factual situations. The peculiar aspect of this branch of the law is that until there is an award covering every factual situation, the practitioner cannot definitely predict the decision of the court. It is clear that such a situation will never come about, and although many jurisdictions have enacted legislation which outlines the boundaries of the courts' decisions, in the last resort, when applying these legislative standards the courts use their common sense. Once this fact is realized there is no need to reconcile the results of all the cases.

Indeed, any practitioner giving advice in this field must content himself and his client with an intelligent guess.

These is another point of interest which we should note, namely, the importance of the trial judge's decision. Here the decision of the trial judge is ex. tremely weighty since an appellate court hesitates to overrule the trial judge's decision unless an important factor was not considered by the trial judge, or unless the award is inordinately high or low in relation to the loss suffered. In other words, the appeal court will only vary the award of damages when the amount of the award is repugnant to common sense, which is seldom the case.

\section{General Principle}

There is no doubt as to the principle which motivated the passing of Lord Campbell's Act' (1846) upon which our own Fatal Accidents Act ${ }^{2}$ is closely patterned. In many cases it has been explained that the Act was meant to give a right of action to persons dependent upon a deceased, against the one who wrongfully caused the death, to recover whatever they have lost because of the death. It provides a means for certain enumerated dependents of the deceased to recover elsewhere the sums the deceased would have paid them if he had remained alive. The nature of the damages is beyond doubt. Rinfret J. said in Littley v. Brooks":

In assessing damages under the Fatal Acridents $A c t$, it is well settled law that the jury are confined to pecuniary loss sustained by the family and cannot take into consideration the mental suffering of the survivors. . . . It is the reasonable expectation of pecuniary advantage by the relatives remaining alive that may be taken into consideration.

${ }^{1}$ (1846) 9 and 10 Vict, c. 93.

2R.S.A. 1955, c. 111.

${ }^{3}$ Littley v. Brooks and C.N.R. [1932] S.C.R. 462 at 470. 
Similarly the Judicial Committee of the Privy Council on an appeal from the Appellate Division of the Supreme Court of Alberta held in Royal Trust v. C.P.R. ${ }^{4}$ that:

When a claim to compensation to families of persons killed through negligence is made, the right to recover is restricted to the amount of actual pecuniary benefit which the family might reasonably have expected to enjoy had the deceased not been killed. It is not competent for a court or a jury to make in addition a compassionate allowance.

The same principle was stated by numerous English cases dating back to the years immediately following the passing of the Act. To carry this principle into operation, it is necessary for the court to calculate the amount of pecuniary benefit which the relatives could have "reasonably expected". I will first set out the way in which the courts reach a total figure representing the payments which might have been expected, and then will deal in turn with the various possible deductions that may be made from the gross figure to give the final amount of damages that may be awarded.

\section{Calculation of Expected Pecuniary Benefit Generally}

Acting on the general principle enunciated above the courts have realised clearly what they wish to do. The greatest difficulty faced by the courts is that arising from the facts. Thus Lord Watson, giving the advice of the Privy Council in Grand Trunk Railway v. Jennings", stated:

In some circumstances that principle admits of easy application; but in others the extent of loss depends upon data which cannot be ascertained with cettainty and must necessarily be a matter of estimate, and, it may be, partly of conjecture. When a man has no means of his own, and earns nothing, it is obvious that his wife or children cannot be pecuniaty losers by his decease. In like manner, when by his death the whole estate from which he derived his income passes to the widow... no statutory claim will be at their instance. A very differenc case arises when the means of the deceased have been exclusively derived from his own exertions, whether physical or intellectual. It then becomes necessary to consider what, but for the accident which terminated his existence, would have been his reasonable pros. pects of life, work and remuneration: and also how far these, if realised, would have conduced to the benefit of the individual claiming compensation.

The method by which the courts should go about attempting to estimate the future prospects of the deceased and the loss likely to result to the dependents is stated in Charlesworth on Negligence' as follows:

When the income of the deceased was derived from his own earnings. it then becomes necessary to consider what, but for the accident which terminated his existence, would have been reasonable prospects of life, work and remuneration; and also how far these, if realised, would have conduced to the benefit of the individual claiming compensation. The manner of arriving at the damages is (a) to ascertain the net income of the deceased available for the support of himself and his dependents; (b) (i) to deduct therefrom such part of his income as the deceased was accustomed to spend upon himself, whether for maintenance or pleasure; or (ii) what should amount to the same thing, to ascertain what part of his net income the deceased was accustomed to spend for the benefit of the dependents; and then (c) to capitalize the difference between the sums (a) and (b) (i) or (b) (ii) having regard to the deceased's expectation of life, the probable duration of his earning capacity, the expectation of life of each of the dependants and the probable duration of the deceased's assistance to each dependant during the joint lives of the deceased and that dependant. From the sum thus ascertained must be deducted any pecunjary advantage received by the dependants in consequence of the deach.

1Royal Trust v. CP.R. [1922] 3 W.W.R. 24 at 25.

see for example, Bradburn v. Great Western Railway Co. (1874) L.R. 10 Ex. 1.

${ }^{B}$ Grand Trunk Railway Co. v. Jennings, (1888) 13 App. Cas. 800 at 803.

'J. Charlesworth, The Law of Negligence, 2nd ed., 1947, p. 554. See also Charlesworth, 3rd ed., 1956, p. 560. 
This passage was approved in Western Trust v. B.A. Oil. ${ }^{8}$

In greater detail, the proper considerations are exhaustively set out by Viscount Simon, delivering the advice of the Privy Council in an appeal from the British Columbia Court of Appeal in Nance v. B.C. Electric Railway'. His Lordship held that:

The claim to damages in the present case falls under two separate heads:

(i) If the deceased had not been killed, but had eked out the full span of life to which in the absence of the accident he could reasonably have looked forward, what sums during that period would he probably have applied out of his income to the maintenance of his wife and family?

(2) In addition to any sum arrived at under the first head, the case has been argued on the assumption common to both parties that according to the law of British Columbia it would be proper to award a sum representing such portion of any additional savings which he would or might have accumulated during the period for which, but for his accident, he would have lived, as on his death at the end of this period would probably have acerued to his wife and family by devolution either on his intestacy or under his will if he made a will.

A proper approach to these questions is in thelr Lordships view one which takes into account and gives due weight to the following factors-the evaluation of some, indeed mose, of them can, at best, be but roughly calculated:

Under the first head-indeed for the purposes of both heads-it is necessary first to estimate what was the deceased man's expectation of life if he had not been killed when he was (let this be " $x$ " years) and next what sums during these $x$ years he would probably have applied to the support of his wife. In fixing $x$, regard must be had not only to his age and bodily healch, but to the possibility of a premature determination of his life by a later accident. In estimating future provision for his wife, the amounts he usually applied in this way are obviously relevant, and often the best evidence available, though not conclusive since, if he had survived, his means might have expanded or shrunk, and his liberality might have grown or wilted. . . Supposing by this method, an estimated annual sum of \$y is arrived at as the sum which would have been applied for the benefit of the plaintiff for $x$ more years, the sum to be awarded is not simply $\$ y$ multiplied by $x$ because the sum is a sum spread over a period of years and must be discounted to as to arrive at its equivalent in the form of a lump sum payable at his death in damages. Then a deduction must further be made for the benefit accruing to the widow from the acceleration of her interest in his estate .... and of her interest in sums payable on a policy ... . on his life; and a furthet allowance must be made for a possibility which might have been realised if he had not been killed but had embarked on his allotted span of $x$ years, viz., the possibility that the wife might have died before he did.

And there is a further possibility to be allowed for-though in most cases it is impossible of evaluation-viz., the possibility that, in the events which have actually happened, the widow mighe remarty in circumstances which would improve her financial position.

This long passage has been set out because it is the first complete analysis of how damages ate to be calculated under the Fatal Accidents Aca. The case has been followed in Alberta. ${ }^{10}$

We must also consider here a line of cases relevant to the questions before us, although not considered in the Nance case. It was pointed out in the recent Northern Ireland case of Brennan v. Gale that the method employed by the Judicial Committee in the Nance decision is not a universal solution to the problem of quantum. Black L.J. held that:

This is a method (Nance) which can readily be followed in the case of a weekly wage earner who leaves a widow and a family of young children but it is not . . capable of provid. ing a simple and complete solution in a complicated case and even in cases where the method is appropriate, difficulties arise in its application.

His Lordship then concludes that the more usual practice is to settle the basic

"Western Trust Co. v. B.A. Oil (1951) 2 W.W.R. (N.S.) 529.

DNance v. B.C. Electric Railzyay Co. (195I) 2 W.W.R. (N.S.) 665 at p. 675 et seq.

10In Donaldson v. Paxliuk (1955) 15 W.W.R. (N.S.) 166.

11 Brennan y. Gale [1949] Nor. Ir. R. 178. 
annual figure which the dependant would presumably receive and apply to it a multiplier which takes into account all the doubts and uncertainties which point to a reduction in the sum to be awarded, rather than to reduce the sum resulting from the calculation according to the principle in the Nance case of the annual sum multiplied by a number of years. This test, however, still involves the problem of selecting the appropriate multiplier. Lord Goddard C.J., in Heatley v. Steel Company of Wales," held that the number is entirely arbitrary and entirely a matter of speculation. In Roughead v. Railway Executive $^{13}$ the number was 10 , while in Brennan v. Gale ${ }^{14}$ it was held that 16 is the upper limit of any calculation of damages which has been affirmed by an appellate tribunal. However, in determining the multiplier, the court will have regard to the deceased's age, expectation of life, state of health, occupation, and probable duration of earning capacity. The method enunciated in Brennan v. Gale has been judicially recognised by the Manitoba Court of Appeal in Roberts v. Semchyshyn ${ }^{\prime 3}$ and the position to date is best summed up in the following quotation from the judgment of Schultz J.A.:

It is correce to say that in many of the British and Irish cases, particularly Roughead v. Railway Executive (supra) and Brennan v. Gale (supra), the method followed is that of taking a datum or basic figure (arrived at by deducting the amount a deceased expended from his income for personal expenses and living expenses) and multiplying by a certain number of years purchase, thus arriving at a lump sum which is further reduced by giving effect to the uncertainties of the circumstances of the particular case. The amount so arrived at constitutes the award. But it is not stated and it does not follow that this is the only means of arriving at an award. From the standpoine of the appellate court, if it appears that the trial judge has taken into consideration the principles and factors he must consider, given them their due weight and has not taken into consideration any irrelevant factor and has not made an award so high or so low as to indicate that obviously he was in error, the award should not be disturbed. It is the result, not the method, which is important.

It would further appear that where employment is of a precarious nature, this factor is also relevant in assessing the lump sum to be awarded as damages. $^{10}$

\section{Amounts Received from Deceased's Estate and Under the Trustee Act}

There is a great deal of law on the question of the effect on claims under the Fatal Accidents Act of the receipt by dependants of money from the estate or of damages under the Trustee Act ${ }^{17}$. The latter is a problem because most often the damages to be awarded under the Trustee Act which go to the estate end up in the hands of one or more of the dependants claiming under the Fatal Accidents Act. Again, the difficulty arises in the application of the principle that under the Fatal Accidents Act what is being awarded is compensation for the actual pecuniary loss caused by the death.

\footnotetext{
12Heatley v. Steel Company of Wales Led. [1953] 1 W.L.R. 405.

${ }^{13}$ Roughead v. Railway Executive (1949) 65 T.L.R. 435.

1Supra, footnote 11 .

${ }^{35}$ Roberts v. Semchyshyn (1956) 20 W.W.R. (N.S.) 219 at 222. Also see Ure et al v. Fagnan and Hume and Rumble Lid. (1957) 22 W.W.R. 289. (T.J. and C.A.), 9 D.L.R. (2d) 480 (C.A., affirmed sub. nom. Fagnan v. Ure et al and Hume and Rumble Lid. [1958] S.C.R. 377, especially per Johnson J.A. in the Appellate Division.

10Ure v. Fagnan, supra per Johnson J.A. See also Baur v. C.P.R. [1937] 3 D.L.R. 258 (Alta. S.C.) per Ewing J., and Sebzda v. Hupke and Buchkowski (1950) 2 W.W.R. 165 at 177 per Boyd McBride J.
}

17 R.S.A. 1955 , c. 346. 
Two questions arise here - what is the effect of the receipt by a dependant of some pecuniary benefit from the estate, apart from Trustee Act payments, and what is the effect of an award under the Trustee Act. As stated, however, it is difficult to separate them in practice.

(a) Trustee Act. The effect of payments under this Act is clear in two situations:

(i) There can be no effect upon Fatal Accidents claims when the sum awarded under the Trustee Act goes to the benefit of persons who are not dependants of the deceased, for only dependants can claim under the Fatal Accidents Act, and, in this situation, their pecuniary loss is not lessened by damages awarded under the Trustee Act.

(ii) Where the Trustee Act payment goes directly and in full to one or more dependants, their claim is reduced by that amount. The two Acts were not meant to give double damages, and this rule is sustained by high authority. In Dowhy v. Lamonlagne, ${ }^{18}$ Dysart J. dealt exhaustively with the problem and decided that double damages could not be awarded. ${ }^{10}$ Dysart J. held that:

The assessment under the Fatal Accidents Act is the full measure, the maximum-of the dependants' damage resulting from the death; the dependant is entitled to receive the sumno more: and whatever he receives from the estate is to be credited as pro lanto payment of his award under the Fatal Accidents Act. Where the amount reccivable from the estate is definitely ascertained ... the judgment should be entered (a) for the estate, for the full amount awarded to the estate, and (b) for the dependants, for the amount awarded them under the Fatal Accidents Act, less the amount receivable from the estate.

If difficulties arise regarding the financial affairs of the estate, the validity of testamentary instruments, or other problems connected with the admin. istration of the deceased's estate, then, according to Dysart J., a fair estimate must be made, and,

when so resolved, the amount found to be coming to the dependants from the estate should then be carried as a credit against their award under the Fatal Accidents Act.

In Alberta, the Appellate Division has given similar rulings ${ }^{20}$ as has the Supreme Court of Canada. ${ }^{21}$ The most recent example of the practical working of this principle occurred in the celebrated case, Ure v. Fagnan, ${ }^{15}$ in which $\mathrm{H}$. J. Macdonald J. held that when considering awards under the Fatal Accidents Act, regard should be had to amounts awarded under the Trustee Act in order to avoid duplication of damages. This decision was upheld on appeal.

As previously indicated, where the Trustee Act damages do not go in full to dependants, they will be set off against Fatal Accidents claims only to the extent that they went to reduce pecuniary loss to dependants.

(b) The Estate Generally.

It is less clear what is the effect upon the damages under the Fatal Accidents

${ }^{1}$ Dowhy v. Lamonlagne [1945] I W.W.R. 81 at p. 85, (Man.).

19Following Rose v. Ford [1937] A.C. 826 (H.L.), Feay v. Barnewell [1938] 1 All E.R. 31, and Daries v. Powell - Duffiryn [1942] A.C. 601.

20Foster v. Kerr [1940] 1 W.W.R. 385 at p. 401 per Ford J.A.

${ }^{21}$ In Ponyicki v. Sarrayama [1943] S.C.R. 197.

28Supra, footnote 19. 
Act of a benefit received from the deceased's estate as a result of his death, but not consisting of damages awarded under the Trustee Act. It could be argued that this benefit should be deducted from the damages because it is a benefit resulting from the deceased's death, and a number of cases seem to say this. ${ }^{23}$ The general principle is set out in Davies v. Powell $D$ uffryn ${ }^{24}$ by Lord Russell of Killowen:

The general rule which has always prevailed in regard to the assessment of damages under the Fatal Accidents Act is well settled, namely, that any benefit accuring to a dependant by the death must be taken into account. Under those Acts, the balance of loss and gain to a dependant must be ascertained, the position of each dependant being considered separately.

The courts in Western Canada seem to have construed the above principle to mean that anything going from the estate to the dependant must be deducted. Thus in Moreton v. MacGregor, ${ }^{20}$ Major J. held that

whatever money is received by the widow from the estate will have to be applied in reduction of the amount awarded to her under the Fatal Accidents Act.

In Alberta, Egbert J. has twice rendered similar decisions. In Maltais v. C.P.R., ${ }^{26}$ his Lordship held that:

There is no question that as the law now stands $I$ must in arriving at damages under the Fatal Accidents Act, take into account the benefit each beneficiary will receive from the estate of the deceased, and that double damages should not be allowed.

A similar decision was given in Shybunka v. Kapolka ${ }^{2 i}$, and other western cases follow the same trend. ${ }^{28}$

However, several decisions of the Privy Council require the estate to be taken into account in a somewhat more restricted manner. Thus in Royal Trust v. C.P.R. ${ }^{20}$ Lord Parmoor said that the Court must take into account the capitalized value to dependants of the share of the future income of the deceased which they would have enjoyed, with proper allowances in respect of the acceleration by reason of the death of the benefits coming to the dependants under the will of the deceased. This trend of thought has been followed both by the Privy Council ${ }^{30}$ and by the Manitoba courts. ${ }^{31}$ Accord. ing to this approach it is the value of the acceleration in devolution of the deceased's estate and not the value of the estate itself which is to be taken into account.

Logically, either of these two approaches could be considered correct depending on the circumstances. Where the estate would not likely or necessarily have gone to the dependants at all, then when the death results in it going wholly to them, the amount should be deducted from the damages. But where the estate would necessarily or probably have gone to the dependant anyway, their only gain from the death is to get the estate sooner, in which

${ }^{23}$ See cases cited at footnote 19.

24 Supro, footnote 19, at p. 606.

${ }^{25}$ Moreton v. MacGregor [1947] 2 W.W.R. 421 at 427 (Man.).

20Maltais v. C.P.R. [1950] 2 W.W.R. 145 at 162, per Egbert J.

27 Shybunka v. Kapolka (1951) 4 W.W.R. (N.S.) 673.

28Sebzda v. Hupka and Buchkowski, supra footnote 16, and Pash v. Registrar of Motor Vehicles, [1949] 1 W.W.R. 225 (Man. Q.B. per Williams C.J.Q.B.).

20Supra footnote 4.

${ }^{80}$ G.T.R. v. Jenings, supra footnote 6, Nance v. B.C. Electric Railyay, supra, footnote 9.

${ }^{31}$ Drewry v. Towns, (1951) 2 W.W.R. (N.S.) 217. 
case only the value of acceleration of the estate should be allowed as a deduction. $^{32}$

\section{Specific Possible Deductions.}

(a) Income Tax - On principle, since sums which the deceased would have had to pay in the future as income tax would reduce the amount from which he could possibly have provided for dependants, they should be deductible from the amount of damages. They could be calculated either by an estimate based on past income taxes, or by calculations based on the future earnings of the deceased. This principle was applied in Ure v. Fagnan ${ }^{33}$ by H. J. Macdonald $\mathrm{J}$ and is further supported by dicta in at least one earlier Canadian case. $^{\text {s4 }}$

(b) Pensions - It is established on good authority that amounts being received as pensions by dependants as a result of the deceased's death are deductible from damages awarded under the Fatal Accidents Act. In Oakes v. The Queen ${ }^{3 \mathrm{~s}}$ the Exchequer Court of Canada held that the amount of a Crown pension to the widow of a deceased serviceman should be deducted from damages awarded due to his death. It should be noted that the statutory provision being considered was one in the Quebec Civil Code, but Thorson P. said that the principle involved was the same as that in the Fatal Accidents Act and cited English authority in support of his decision. ${ }^{36}$ The Alberta courts appear to follow this decision and the principle may be said to be firmly established. $^{37}$

(c) Workmen's Compensation Payments - It has been held that when an award has been made for the death of a workman under the Workmen's Compensation Act and then an action is brought in the ordinary way for damages under the Fatal Accidents Acts, the loss should be calculated in the ordinary way and then the amount awarded under Workmen's Compensation deducted. ${ }^{38}$

(d) Insurance - The question whether any deductions may be made as a result of life insurance accruing to dependants now appears to be clearly settled in Alberta. The Fatal Accidents Act ${ }^{30}$ provides:

In assessing damages in an action brought under this Act, there shall not be caken into account a sum paid or payable on the death of the deceased under a contract of assurance or insurance.

32This approach was followed in Ure v. Fagnan, per H. J. Macdonald J. and upheld on appeal to the Appellate Division of the Supreme Court of Alberta. See per Johnson J.A. (1957) 9 D.L.R. (2d) at p. 489 where his Lordship clearly states that the entire value of the estate payable to dependants is not necessarily to be deducted from the award of damages under the Fatal Accidents Act.

s3supra, footnote 15.

34 Moert v. Abraham and Johnston [1944] 2 W.W.R. 381 at 382 per Coady J.

asOakes v. The Queen [1954] Ex. C. R. 572.

soparticularly Baker v. Dalgleish Steam Shipping, [1922] 1 K.B. 361, and Johnson v. Hill, 61 T.L.R. 398, [1945] 2 All E.R. 272.

37 Ure v. Fagnan, supra, footnote 15.

${ }^{38}$ Maloney v. Davidson [1951] Que. S. C. 408.

99Fatal Accidents Act, supra, footnote 2, s. 6. 
Notwithstanding this section, it appears clear that the above section does not prevent deduction of sums which would have been payable as premiums if the deceased had not died. ${ }^{40}$

\section{Quantum generally.}

In general, Canadian courts have been reluctant to award large amounts under the Fatal Accidents Acts." The recent decision in Ure v. Fagnan to which frequent reference has been made in this article appears to be a new point of departure on the road to more adequate compensation. In addition this decision has demonstrated that there is no one road to the computation of damages as apparently had been thought following the $N$ ance decision. It appears that now the tests utilized in the Roughead and Brennan v. Gale decisions ${ }^{22}$ are equally appropriate in certain instances. Indeed, the test to be utilized appears to be any one which arrives at a substantially just conclusion, ${ }^{43}$ and if the amount arrived at appears to be substantially just, the trial court need have no fear of being overruled by the appellate courts. With the general principles now settled, and a substantial freedom given to the trial courts, it is to be hoped that future decisions will be more in accord with the economics of life in the modern era.

10 Ure v. Fagnan, supra, footnote 15. See also Baker v. Dalgleish, supra, footnote 36. A similar section to our section 6 was then in force in England, although this section is not zeferred to specifically in the decision of the Court. Most other Canadian Provinces appear not to have similar sections in effect, nor are English cases decided prior to 1908 , in which year the English provision corresponding to our own was put into effect, of any great assistance. In Saskatchewan and Ontario it has, however, been found necessary to insert specific provisions in the Fatal Accidents Act to prevent reference to future premiums payable. See Pollard v. Chipperfield et al, (1952) 7 W.W.R. (N.S.) 596, and Poyner v. Ferguson [1955] O.W.N. 1.

1'The following examples may illustrate the point. In Dreary v. Towns, supra, footnote 31, deceased was 50 years of age, in good health, industrious, with extensive lands, imple. ments and no debts, and left an estate of $\$ 15,000$. He left five dependants. $\$ 15,000$ damages were awarded. In Mocrt v. Abraham and Johnson National Storage, supra footnote 34 , deceased was a brewmaster earning $\$ 400.00$ per month, was aged 35 , his prospects were excellent, and left four dependants. Damages of $\$ 25,000$ were assessed. In Royal Trust v. C.P.R., supra, footnote 4, the deceased was a medical specialist, aged 46, and earning approximately $\$ 15,000$ per year. Damages to his wife and son under the Fatal Accidents Act were $\$ 25,000$ and $\$ 15,000$ respectively. See also Tower v. Murphy [1954] 2 D.L.R., Polllard v. Chipperfield, (1952) 7 W.W.R. (NS.) 596 (Sask.), Foster v. Kerr, [1940] I W.W.R. 401 (Alta.), Donaldson v. Paziliuk (1955) 15 W.W.R. (N.S.) 166 (Alta.) and Baur v. C.P.R., [1937] 3 D.L.R. 258 (Alta.), all examples of conservative awards of damages. In Ure $v$. Fagnan, the deceased was aged 43 , had an income of $\$ 11,000$ per annum as a Cabinet Minister and engaged in farming, an occupation which, in his case, had yet to show a profit, although future prospects were good. His wife and children were awarded under the Fatal Accidents Act the hitherto unknown sum of $\$ 75,000$. Viewed against earlier and similar situations, the award seems a departure from judicial conservatism.

12 Supra footnotes 13 and 11.

49 Ure v. Fagnan, supra, footnote 15, Appellate Division, per Johnson J.A. and Boyd MeBride, J.A. 